\title{
Polymorphus Hemangioendothelioma
}

National Cancer Institute

\section{Source}

National Cancer Institute. Polymorphus Hemangioendothelioma. NCI Thesaurus. Code C45476.

An intermediate, rarely metastasizing blood vessel neoplasm. It is characterized by the presence of a polymorphic cellular infiltrate. 